\title{
RUDYARD KIPLING'S TACTICAL IMPRESSIONISM
}

\author{
By Chris Ortiz y Prentice
}

A STORY TITLED "THE IMPRESSIONISTS" that was published in 1897 should have something to say about art, but does it? The sixth installment in Rudyard Kipling's Stalky \& Co. series, "The Impressionists" follows the antics of M'Turk, Stalky, and Beetle, three cunning boys at a dreary English military preparatory school. Suspecting these boys of cheating on their schoolwork, housemaster Mr. Prout turns them out of their private study into the main house dormitory. For revenge, and hoping to win back their room, Stalky \& Co. become agents provocateurs. They start a fight in their house and manage to involve the other housemasters' houses: "Under cover of the confusion the three escaped to the corridor, whence they called in and sent up passers-by to the fray. 'Rescue, King's! King's! King's! Number Twelve form-room! Rescue, Prout's - Prout's! Rescue, Macrea's! Rescue, Hartopp's!'” (102). The three boys then allow Mr. Prout to overhear a conversation that makes money-lending seem common practice in the houses: "'Where's that shillin' you owe me?' said Beetle suddenly. Stalky could not see Prout behind him, but returned the lead without a quaver. 'I only owed you ninepence, you old usurer"' (103). Stalky \& Co. rile up the other boys by telling ghost stories and spreading slanderous ditties; they turn the house against the prefects and undermine Mr. Prout's authority; and in the end they win back their room, but they are also found out by the headmaster, who mixes corporeal punishment with his admonishments: "There is a limit - one finds it by experience, Beetle - beyond which it is never safe to pursue private vendettas, because - don't move - sooner or later one comes - into collision with the - higher authority, who has studied the animal. Et ego - M'Turk, please - in Arcadia vixi" (117). The boys take the headmaster's attentions as a compliment, and they take his advice. Never again do they stake the school's peace in the pursuit of their own ends.

From this distance, "The Impressionists" seems a far cry from its namesake, capitalI Impressionism, the movement commonly associated with figures like Monet, Conrad, Pater, and Proust. Yet, as I hope to show here, this Impressionism and turn-of-the-century Impressionist discourse inspire much of the story's plot, dialogue, and reference. The connections between the story and capital-I Impressionism may be discovered by tracking Kipling's prior thinking about Impressionism in his novel about painters The Light That Failed (1890) and in his reflections on Japonisme in From Sea to Sea (1889). In these works, Kipling examines the artist's duty to tell the truth and experiments with rhetorical maneuvers aimed at disarming readers' prejudices. In "The Impressionists" - which makes explicit reference to these earlier works - Kipling illustrates how to gain by telling lies that exploit a 
person's prejudices. At the crux of Kipling's theorization of Impressionism is an insight into the novel possibility inscribed in the Latin root, impressio, which means "irruption, onset, attack" ("impression"). The impression makes an attack on the understanding to gain assent. The artist may use the belief-rendering capacities of the impression not only to overcome incredulity but also to mislead and manipulate.

Scholars have tended to think about Impressionism in terms of mimesis and modernity. "Impressionism," writes Adam Parkes in A Sense of Shock: The Impact of Impressionism on Modern British and Irish Writing (2011), "might represent aesthetic adaptation to the changing conditions of modernity; it might even be understood as an appropriate means of reflecting the deluge of sensations back to itself" (12). In turn-of-the-century Impressionist discourse, the artist is frequently envisioned as helping the bewildered to assimilate their impressions. Nietzsche discussed "Modernity" in the 1880s, complaining that "the abundance of disparate impressions [has become] greater than ever" (47), and thinkers like Georg Simmel, Freud and William James similarly theorized modernity in terms of an onrush of "impressions." "The task [of the artist]," as Conrad famously put it, "is to hold up unquestioningly, without choice and without fear, the rescued fragment before all eyes in the light of a sincere mood" ("Preface" xlix). ${ }^{1}$

In this essay, I want to keep Kipling in focus as an artist responding to modernity like other capital-I Impressionists. Viewed as mimesis, Impressionism looks like the elite property of the Aesthete, signaling epistemological concerns shared by painters, critics, novelists, and philosophers. Viewed as tactics, Impressionism looks like the commonplace property of the schoolboy, signaling scrappy concerns shared by crammers, subalterns, connivers, and survivors. In the texts I read here, Kipling's artistic ideals may be seen to emerge, as if dialectically, from a never fully synthesized conception of Impressionism, as mimesis and as tactics, as art and as artifice, as fine and as vulgar, as telling the truth and as deception, as community-building and as an act of war. In what follows, we see Kipling approving of two different uses of Impressionism: by the artist, mimetically, to stimulate the imagination to a wider sympathy and thereby fend off the anomie and malaise caused by modernity's onrush of impressions and by those made precarious by modernity, tactically, to utilize impressions to survive or gain comeuppance. If modernity's bewildering quality sets the stage for "a wide game," as Kipling wrote, the propagandistic deployment of impressions may also sow discord and lead to anarchy. Kipling thus held anxieties about tactical Impressionism. "The Village That Voted the Earth Was Flat" (1913) portrays tactical Impressionism as setting loose forces of anomie and distrust made possible by the "Age of Acceleration." In Kipling's depiction of modernity - exemplified by "Mrs. Bathurst" (1904) - foremost among what threatens the mind, body, soul, and finally the social order, is the impression itself.

Critics have called attention recently to Stalky \& Co.'s ideological discourses of manliness and shame, showing how these shaped Britain's middle class into conformity with conservative imperialist mindsets. ${ }^{2}$ In certain instances in Stalky \& Co., tactical Impressionism looks very much like a weapon of imperialist war and colonial control. In "Slaves of the Lamp: Part II" (1897), for example, Stalky helps defend a British fort in the northwest of India. The Malôts and the Khye-Kheens - fictionalized names for two indigenous groups - have put away past antagonisms to oust the British. In the middle of the night, Stalky sneaks across enemy lines and begins firing from the Malôts's line on the Khye-Kheens. Lending an impression in which one's adversary is predisposed to believe - in this case that a newly formed ally has turned traitor - is shown to be a favored tactic of Stalky, 
both as a boy and as a soldier in the British Empire. From the perspective this essay develops, "Slaves of the Lamp: Part II" does not valorize the British Empire but the underdog's use of tactical Impressionism for survival. The story emphasizes the precariousness of life in the British Army: despite being agents of British "masters," there is nothing to ensure that the British soldiers will not die in battle. To his credit, Kipling did not need to imagine Britain in the role of the underdog to approve of the tactical Impressionist's ability to overcome a stronger force through cunning. In "On the City Wall" (1888), colonial subjects Lalun and Wali Dad use tactical Impressionism to outwit and defeat the British authorities. ${ }^{3}$ Kipling derives the limits of ethical Impressionism from his sense of justice, his sympathy for the imperiled, and his care for the bewildered.

\section{Mimetic Impressionism}

IMPRESSIONISM HAS BEEN DESCRIBED as a major epistemic shift, dating from David Hume's distinction between "ideas" and the direct "impressions" of the five senses, playing out across a number of artistic media, reaching an apotheosis sometime in the later part of the nineteenth century, and serving as the grounds for modernism. ${ }^{4}$ Among writers, Impressionism has been associated with Walter Pater, Henry James, Joseph Conrad, Ford Madox Ford (a self-avowed Impressionist), Marcel Proust, Stephen Crane (whom Conrad called "the only impressionist, and only an impressionist" [CL 1: 416]), Frank Norris, Anton Chekov, and Katherine Mansfield. ${ }^{5}$ Max Saunders has theorized Impressionism's influence on modernism, arguing that,

\footnotetext{
The gem-like flame with which Pater wants to burn; the wondering or haunted consciousnesses of James's novels; Conrad's rigor in trying "to make you see"; the modernist epiphanies of Proust, Joyce, and Woolf: all these (and one could add others: Lawrence's visionary vitalism; Eliot's Tiresias foresuffering all; Pound's desire to reconnect with the divine energies of Homer or Dante) represent a specific paradigm, which corresponds to a new way of thinking about how the mind works (where phenomenology, pragmatism, and Bergsonian vitalism coexist), about the experience of knowing, and the relationship between perceiving and understanding. (206-07)
}

In Literary Impressionism and Modernist Aesthetics (2001), Jesse Matz argues that specifically literary Impressionism should be defined not as any special reliance on description but as a special reliance on or skepticism about the capacity of the "impression," and by extension "impressionist" writing, to transcend subjective perception. Paul Armstrong defines Impressionism in Conrad, James, and Ford as a "Challenge of Bewilderment," bespeaking a conservative politics and an invitation "to develop greater self-consciousness about the workings of consciousness in representation and interpretation" (25). Various critics have ascribed the causes for the intrusion of bewilderment in modern fiction to an "Age of Acceleration," characterized by, on the one hand, urbanization, faster, more extensive means of travel and communication, new technologies, rising literacy, and, on the other hand, a dissolution of Victorian beliefs and assumptions. ${ }^{6}$ Fredric Jameson has argued that Impressionism emerged to compensate subjects for the deadening and socially destructive processes of Taylorization (227-37). Impressionism can also be thought of more narrowly, as one among several neologisms circulating in the second half of the nineteenth 
century, invented to describe trends seen to diverge from classical, orthodox, academic, or established schools of thought, particularly those concerning artistic creation.

When Kipling has been considered in connection with Impressionism, it has been for such qualities in his literary writing as its sensory descriptiveness, its suggestive understatement, its telling detail, its pared down and carefully organized forms, its practiced ambiguity and sense of mystery. Critics immediately recognized Impressionist attributes in Kipling's work. Gleeson White, for instance, advised Kipling in Letters to Eminent Hands (1892) that, "Like a clever impressionist your aim is for colour, air and light, with the supreme moment only" (59), while W. S. Sichel considered Kipling along with Pierre Loti as "modern word-colorists" in his 1897 Quarterly Review article, "Fathers of Literary Impressionism in England" (194). Because its semi-autobiographical protagonist is a painter and one of its minor characters is named only "the red-haired impressionist girl," critics have tended to track Kipling's thinking about Impressionism to his first novel, The Light That Failed. The novel follows English painter and war correspondent, Dick Heldar, whose artistic allegiances shift away from the establishment Neoclassicists in the Académie des Beaux Arts, where drawing and detail are emphasized, to the radical Impressionists, who stress color, speed of composition, and the relevance of the observer's emotional attachment to the subject. Kipling's family connections to painters and Paris made Impressionism a natural point of reference for his own ideas about art, ${ }^{7}$ and as Richard Berrong argues, "Kipling may well have found certain aspects of this new style of painting to be convenient ways of talking about what he wanted to do, or already saw himself as doing, in his own work" (35). Charles Carrington, Kipling's first official biographer, thought that the "daring portrait of the "red-haired girl"' in The Light That Failed, "dabbed on the canvas, en plein air, with a few bold strokes in primary colours, is itself an impressionist masterpiece. Few other writers can convey light and colour in words, as vividly as Rudyard Kipling" (615). In an often referenced but rarely quoted book, J. M. S. Tompkins similarly compliments "that incandescence of the imagination that saw the light slipping through the oar-holes of the galley's lower deck, or Dravot walking among the pines, like a big red devil, with the sun on his crown and his beard" (114). Discussing the descriptive writing in Kim, Tompkins writes:

\footnotetext{
Much of the charm of the pictures is in the lighting, and this varies continually. The sun sets red through a mango-grove or washes across the gold-coloured grass of a hillside; the lights prick out in Simla; the Sahiba's palanquin swings round the homestead with its escort of smoky torches, and the old servitor curls his white moustaches savagely in the young moonlight; and then the dawn rises cold on the waking camps, the railway-sidings, the little villages with temples and the cool, cut stone of the cells of the Jain monks. (26)
}

As Tompkins concludes, Kipling "never cared to write a neutral-coloured prose," and indeed his words convey not only light and colors but the whole sensual gamut (245). Kipling himself recognized that, especially in his earlier tales, "it was necessary that every word should tell, carry, weigh, taste and, if need were, smell," and that "I made my own experiments in the weights, colors, perfumes, and attributes of words in relation to other words, either as read aloud so that they may hold the ear, or, scattered over the page, draw the eye" (Something 120, 43-44).

As critics have seen, Kipling's literary Impressionism goes beyond the use of descriptive language. It is significant that Tompkins chose to explicate Kipling's tales as "Art," a matter of 
frames and focal points, lightings and patterns, dramatic and symbolic imagery, "viewable" in a single sitting. "As his work deepened," Tompkins argued, "the intricacies sank into its grain, and he produced that figured art ... where the full meaning has to be developed from image, symbol and hint, and the reader must also be an investigator" (258). Kipling's mature Impressionism gives the same challenge of bewilderment Paul Armstrong finds in the novels of James, Conrad, and Ford. Louis Menand has regarded "Mrs. Bathurst" as an exemplary Impressionist text because it draws parallels between the processes of consciousness and new technologies of factual yet illusory representation, such as the photograph and cinematograph (160-64). One is reminded of Michael Fried's argument that "in Manet's paintings of the first half of the 1860s photography and Japanese woodblocks interpret one another.... Manet imagined photographs - which in the early 1860s visibly bore the marks of a certain constitutive duration (i.e. stillness, heldness) - to have been produced as if instantaneously, in a flash or rather by a blow, a single powerful woodblock-like impression" (327). In "Mrs. Bathurst," the men compare their single powerful woodblock-like impressions and end up mystified, causing Pyecroft to wonder about perception's power to exceed understanding. What Tompkins wrote about Kipling's Impressionist "Art" could be said of other literary Impressionists: "Kipling's work is full of deliberate gaps and abstentions. We are brought to the outside of the shut door or the edge of the gulf, and, if we have used our human understanding and our keenest attention, we have sufficient knowledge of what is going on behind the one or in the depth of the other" (155). In the infamously obscure "Mrs. Bathurst" as in some other of Kipling's stories, we do not have sufficient knowledge, yet this seems to be part of the point. As the poet had remarked early in his career: "A stone's throw out on either hand / From that well-ordered road we tread, / And all the world is wild and strange" (Verse 8). To depict this wild and strange world, Kipling developed a fully literary, mimetic Impressionism.

\section{Towards Tactical Impressionism}

KIPLING'S IMPRESSIONISM has been explained only in its mimetic aspects, yet the travelogue From Sea to Sea (1889) suggests that Kipling began to conceive of the Impressionist's art in terms of tactics as he became frustrated with the demands of verisimilitude. In this book, Kipling collected his travel reports or "letters" written between 1887 and 1889 for the Anglo-Indian audience of the Pioneer, an English-language Indian newspaper. Early in the book, the impression's mimetic capacities are tested and found wanting. After describing the Taj Mahal, for instance, the "Englishman" - Kipling's tongue-in-cheek name for his first-person narrator - complains: "It may be, too, that each must view the Taj for himself with his own eyes, working out his own interpretation of the sight. It is certain that no man can in cold blood and colder ink set down his impressions if he has been in the least moved" (1: 6). In this instance, as in others, "impression" connotes something different, and seemingly more than, either thoughts or sensations. "An impression is never simply a feeling, a thought, or a sensation," explains Matz: "It partakes, rather, of a mode of experience that is neither sensuous nor rational, neither felt nor thought, but somewhere in between" (16). ${ }^{8}$ Kipling evidently shared this technical definition of the impression. When the Englishman's travelling companion - the "Professor" (Samuel Alexander Hill) - asks, "What have you done? What have you seen?" the Englishman responds: "Nothing. I've accumulated a lot of impressions of no use to any one but the owner" (1:395). For Kipling, having "been moved" 
renders a writer unable to "set down" his impressions. Writing is just too slow: the blood cools while the head works, and the impression is lost. What is then produced, being untrue to the original impression, will fail to convince. Travel writing must content itself with, as the Englishman says, "itinerary" - an attempt at factual descriptions of sights, sounds, smells, tastes, textures - or, as in another instance, ideas: "It is good, good beyond expression, to see the sun rise upon a strange land and to know that you have only to go forward and possess that land - that it will dower you before the day is ended with a hundred new impressions and, perhaps, one idea" (1: 136). "Perhaps," if one is lucky. Impressions are desirable to the traveler but, regrettably, useless to the writer who would convey those impressions; whereas Ideas, because they can be communicated, are what the travel writer really wants.

We get an idea from the travelogues of the kinds of problems Kipling saw as intervening between the earnest Impressionist's desire to communicate with his audience and the audience's capacity to believe in the truth of what is being shown. These obstacles are both epistemological and social. In painting, the act of composition and the moment of experience can be conflated into one and the same process, that of Impressionism. Heldar's Impressionist masterpiece in The Light That Failed, "Melancholia," is shown to represent not so much Bessie, the sitter, as Heldar's own internal turmoil (the loss of his sight, his increasing dependence on drink, his broken heart). The "truth" of Heldar's painting is in the painting's existence; the painting is itself the impression. Literary Impressionism, by contrast, cannot hope to achieve this conflation of experience and expression. But there are further difficulties: Because experience is embodied, words must suggest and evoke rather than relate and describe. One must rely, therefore, upon style, but because one is always speaking within an embedded rhetorical situation, the style of earnest evocation is not so simply achieved.

Kipling's most revealing theorizations of Impressionism in From Sea to Sea occur in the chapters recounting his visit to Japan. When Kipling made his visit, Japan was known in Europe as a source of artistic innovation and as a bellicose empire. Many of Kipling's contemporaries would have associated Impressionism with Japonisme. Japonisme evolved from an exoticist penchant for Japanese objects - "for example, Japanese lacquers, ivories, ceramics, textiles, medicine boxes, and ornamental sword guards" - that swept through Europe, especially France, after Japan opened its borders in 1854 (Wichmann 8). Artists and critics began to draw principles from Japanese art as it was put on display at the World's Fairs and Expositions, and as more Westerners traveled to Japan. "To the Impressionists and their second-generation successors," explains art historian Siegfried Wichmann, "Japonisme spelt liberation, the revelation of techniques which released them from the old traditional concepts of classical modeling taught at the academies" (10). More specifically: "From the 1860 s to the 1890 s, the themes of Japonisme provided an exciting new direction for artists such as James Abbott McNeill Whistler (1834-1903), Édouard Manet (1832-83) and Claude Monet (1840-1926), and authors such as the de Goncourt brothers, Guy de Maupassant and Pierre Loti ... and [later] Vincent van Gogh (1853-90) and Paul Gauguin (1848-1903)" (Lambourne 32). As Yoko Chiba notes, Whistler's influence bound up Impressionism with Japonisme for British writers such as Swinburne, Wilde, and Henley (10-11). According to Yeats in an 1892 essay, "a distinguished member of the Gosse, Lang and Dobson school" wrote: "He is no poet who would not go to Japan for a new form" (144).

In his chapters on Japan, Kipling explores the limits of literary Impressionism. The problems of mimetic travel writing are particularly pronounced when the destination is 
Japan and the traveler is a European writing for Europeans. The reason is that Japonisme complicates any attempt at verisimilitude. Kipling draws attention to this problem in the first paragraph of an original draft of the chapters. The Englishman begins by advising the reader, "Never believe anything that Mister Oscar Wilde tells you" because he is "a long-toothed liar!": "Among other things he, with his tongue in his brazen cheek, averred that there was no such a place as Japan - that it had been created by fans and picture-books just as he himself had been created by pottery and fragments of coloured cloth" (qtd. by Ricketts 28). The reference is to "The Decay of Lying" (1889), in which Vivian claims that Impressionism is not so much influenced by Japanese art as Japanese aesthetics are a European Impressionist construction (939). Kipling's Englishman must preempt the sophisticated reader's skepticism about the reality of the Impressionists' Japan if he wants to represent Japan using the techniques of mimetic Impressionism. Interestingly, the editors of The Pioneer struck out this passage (Ricketts 31), perhaps because they perceived that the remarks were aimed at London and not Anglo-Indian readers.

The second paragraph in the original draft combines literary Impressionism with wry commentary to persuade the reader of the reality of what is described. The Englishman writes of looking out his porthole to see "two great grey rocks studded and streaked with green and crowned by two stunted blue-black pines." The description here is painterly, drawing the attention to colors and arrangement, smoothing out or putting a point on words through alliteration and meter. The Englishman describes seeing an "indigo-blue boy with an old ivory face and a musical voice" and a boat in the harbor with an "ivory-white frilled sail." These images, painted in words, inspire the Englishman to comment on their seeming artificiality. They make, he admits, "a panel from a Japanese screen." Yet, the Englishman attests to the reality of the Impressionists' Japan: "I saw that the land was not a lie." Japan really is as it has been depicted in books: "Japan, whence the camphor and the lacquer and the sharkskin swords come; among - what was it the books said? - a nation of artists" (291).

Harry Ricketts has interpreted this opening as "shadow-boxing" in preparation for Kipling's arrival in literary London "where Wilde held court": "Having playfully dismissed Wilde's aestheticised version of Japan with a faux naif display of Anglo-Indian literalism, Kipling now made it his own. With deliberate irony, his descriptive writing ... absolutely bore out Wilde's contention that the only Japan available to us is an artistic construct" (30). At the same time, however, the Englishman is contending that Japan really is a nation of artists and that it really does look like an Impressionist painting. The persuasive gambit of the opening paragraphs is tantamount to saying, "You would not believe me if I told you what I saw." This pattern of writing is repeated throughout the Japanese chapters: Kipling constructs precise impressions that synthesize symbol and sensation, and he accompanies these exercises in literary Impressionism with a number of rhetorical techniques aimed at disarming the reader's incredulity. At the end of the chapters, the Professor asks the Englishman, "What sort of mental impression do you carry away?" The first impression the Englishman offers is, "A tea-girl in fawn-coloured crêpe under a cherry tree all blossom." This is a postcard image of Japan, the modifier "all blossom" neatly arranged to apply to both the tree and tea-girl. The next impression directs the reader, painter-like, to look "behind" the tea-girl at images that skirt the line between object and symbol: "green pines, two babies, and a hog-backed bridge spanning a bottle-green river running over blue boulders." In the following impression, the Englishman begins by directing the reader's visual imagination but then slides perceptibly into symbolic language: "In the foreground a little policeman in badly 
fitting Europe clothes drinking tea from blue and white china on a black lacquered stand." The European clothes are badly fitting because, as the preceding chapters have indicated, the Englishman disapproves of Japanese adoption of Western culture and society. The final two impressions, by veering away from political signification, make it figure ambiguously as a subtext: "'Fleecy white clouds above and a cold wind up the street,' I said, summarising hastily." It is possible that the cold wind up the street represents the Aesthete's foreboding about the militaristic dimension of Japanese society. ${ }^{9}$ These final impressions of Japan strive to combine descriptive and symbolic language. They are made to seem indicative of some "truer" reality in which sensation and meaning are mutually constitutive, and to this extent, they derive from literary-Impressionist theory. ${ }^{10}$ Yet, tellingly, the Englishman cannot allow the impressions to stand by themselves. They are supported rather than undercut by a proviso - "I said, summarising hastily" - and then by a disavowal - "But what's the good of writing impressions? Every man has to get his own at first hand. Suppose I give an itinerary of what we saw?" (1: 421). The rhetorical manipulation here is that of saying, "Believe me if you want to."

In the chapters on Japan, then, Kipling offers "impressions" while disarming his readers' preconceptions. If Kipling was able to find a "new form" in Japan, it was a new understanding of Impressionism as tactics in addition to mimesis. The connection between tactical Impressionism and Japonisme is made explicit when, in "The Impressionists," M'Turk analogizes Stalky \& Co. tactics to a form of Japanese wrestling: "These wrestlerchaps have got some sort of trick that lets the other chap do all the work. Then they give a little wriggle, and he upsets himself. It's called shibbuwichee or tokonoma, or somethin", (115). The significance of this passage to Kipling's thinking about Impressionism becomes clear when we situate it within the story's use of the word "impression."

\section{3. "The Impressionists"}

IN “THE IMPRESSIONISTS," Stalky \& Co. deploy impressions on Mr. Prout that are ingeniously designed to make him act as the boys wish him to. The impressions stoke Mr. Prout's fears, confirm his prejudices, tease his vanity, and attack his equanimity. Mr. Prout is represented as a typical Victorian housemaster: "Prout expounded to Beetle the enormity of moneylending, which, like everything except compulsory cricket, corrupted houses and destroyed good feeling among boys, made youth cold and calculating, and opened the door to all evil" (105). The fight between the houses earlier in the day attests to Mr. Prout that good feeling has been destroyed among boys through money-lending and other corrupting practices. But, of course, Stalky \& Co. triggered the fight and invented the story about money-lending so that Mr. Prout would become convinced that good feeling has been destroyed among the boys.

Mr. Prout's self-assurance makes him easy prey to the tactical Impressionists. Beetle takes aim at Mr. Prout's vanity and invents a tune, which he knows will please the younger boys for its catchiness and the safe rebellion it affords. Beetle whispers the ditty in a child's ear, and it is sung around the school by day's end:

Oh, Prout he is a nobleman, a nobleman, a nobleman!

Our Heffy is a nobleman -

He does an awful lot, 
Because his popularity -

Oh, pop-u-pop-u-larity -

His giddy popularity

Would suffer did he not! (109)

By this stage, writes the narrator, "The game was developing itself almost automatically" (103). The fight in the school has put the boys on edge and made them insubordinate. Mr. Prout is letting his worst fears run wild and begins to feel as if "mysteries hedged him on all sides" (108). The narrator explains how Stalky \& Co.'s inventions give rise to conspiratorial behavior among the other boys:

When a House is thoroughly upset, however good its conscience, it breaks into knots and coteries small gatherings in the twilight, box-room committees, and groups in the corridor. And when from group to group, with an immense affectation of secrecy, three wicked boys steal, crying 'Cave' when there is no need of caution, and whispering 'Don't tell!' on the heels of trumpery confidences that instant invented, a very fine air of plot and intrigue can be woven round such a House. (108)

Mr. Prout becomes convinced of the degradation of the schools' social relations when he overhears one boy saying, "Shut up, Beetle; it's too beastly." Inevitably, the housemaster assumes Beetle has been "perverting the juniors" (114), that is, talking about sex, probably of a homosexual variety. In fact, Beetle had only been telling a ghost story but he is delighted with the effect, although he resents the implication.

Vaguely perceiving the cause of the disorder, Mr. Prout decides to return Stalky \& Co. to their private room. The second half of the story opens with the school chaplain making a visit to the three troublemakers. To the chaplain's question, "But why in the world didn't you explain to Mr. Prout, instead of leaving him under the impression - ", Beetle insists: "I was too truthful. I always am. You see, he was under an impression, Padre, and I suppose I ought to have corrected that impression; but of course I couldn't be quite certain that his House wasn't given over to money-lendin', could I?" (114-15). As the chaplain points out, this is a specious argument; when Mr. Prout had asked Beetle: "I wish to know whether you are in the habit of advancing money to your associates Beetle?" Beetle responded, "No, sir; not as a general rule, sir" (104). Beetle's answer is ingenious because, while the truth, it advances the wrong impression. M'Turk gloats at Beetle's interpretive maneuver, noting about Prout: "He is quick to get an impression, ain't he?" (116). The chaplain, picking up on Stalky \& Co.'s idea of Impressionism, quips: "My own private impression is that all three of you will infallibly be hanged" (115).

During this same conversation, M'Turk compares Stalky \& Co. to Japanese wrestlers. Bradley Deane has read the passage in the context of Japan's place in British conservative ideology. According to Deane, M'Turk's reference is to Bushido and the samurai tradition of Japan, and the allusion is meant to recall martial virtues of obedience, stoicism, and aggression associated in England with Japan (140). Yet M'Turk's mistranslations of Judo or Ju-Jitsu point not so much to martial Japan as to the "nation of artists" Kipling writes about in From Sea to Sea. A tokonoma is "a recess in a Japanese room constituting its focal point and usually containing a hanging scroll picture and a flower arrangement" (Page n. pag.). Kipling writes of a tokonoma in the letters on Japan in From Sea to Sea: "The tokonoma, recess aforementioned, held one scroll-picture of bats wheeling in the twilight, a bamboo flower-holder, and yellow 
flowers" (1: 301). Even more suggestive is "shibbuwichee," which, although it does not appear in the travelogue, we may assume Kipling learned either from his travels or from his reading. Shibuichi refers to an alloy in popular use for engravings and ornamental fittings, for impressions - a highly tangential reference but not an altogether impossible one for the son of an engraver ("shibuichi"). Possibly Kipling conflated shibuichi with shibui, a commonplace but complex word often used to denote an aesthetic quality of simple stylishness or understated and thus profound beauty ("shibui"). In a scholarly assessment of the word's etymology, Kawakita asserts that shibui connotes a set of principles within which, "Flashy individualism and showy, wasteful decoration are not merely unnecessary: they are harmful" (41). It is worth noting that shibui came to include a description of the esprit de corps of those baseball players who are essential to the team's success but do not make showy plays (Kawakita 35). As in the Stalky variety of tactical Impressionism, shibui denotes an aesthetic quality that makes an agonistic virtue of understatement.

Tactical Impressionism is an effect-oriented art, aiming more to stimulate than simulate the psychology of perception. It is a manipulation of prejudices not a transmission of felt reality. An advanced form of lying, it exploits prejudices and creates mistrust. It is revealing of Kipling's anxieties about tactical Impressionism that he does not allow Stalky \& Co. to go unpunished. The trio is found out at the end of story by the headmaster, "a man more subtle than them all" (116), who punishes the boys for misbehavior he never specifies: "There's a certain flagrant injustice about this that ought to appeal to - your temperament" (117). The pattern of hyphenation here recalls probably the most recognizable signature of literary Impressionism; the "appeal to - your temperament" parallels the Conradian pronouncement that, "Fiction - if it at all aspires to art - appeals to temperament" ("Preface" xlviii); while the marks the headmaster's lashings produce on the boys' bodies are remarkably described as bearing "a certain clarity of outline that stamps the work of the artist" (117). This clarity contrasts sharply with the story's pervasive atmosphere of fakery and cribbing. Order has been restored, and the boys "aren't wrathy" (118). Instead, they receive the headmaster's punishment as a compliment, since it takes an "artist" to know one. Moreover, the "artist" has restored good faith in the community by perceiving the truth and ensuring justice.

Kipling's anxieties about tactical Impressionism in this story are recognizably those of a capital-I Impressionist. If the Impressionists' skepticism was right for the times, it was not only on account of advances in the physical sciences which drew attention to the relay between sensation and ideation but also and perhaps a fortiori because Impressionists and their audiences experienced modernity as a bewilderment. ${ }^{11}$ In Impressionist fiction, atomism, solipsism, and anarchy lurk behind what Paul Armstrong has called "the drama of interpretation." 12 In Stalky \& Co.'s hands, Impressionist suggestiveness becomes sensationalism, opportunism, rumor spreading, and falsification. The purpose of the boys' subterfuge is to gain their personal objectives: revenge and their private study. The headmaster is there to ensure that no lasting harm is done to the community of the school through the boys' prejudice-stoking insinuations. In "The Impressionists," Stalky \& Co. and the headmaster can both "win," but for reasons we shall now consider, Kipling did not always choose such a utopic ending for his stories about tactical Impressionism. In "The Village That Voted the Earth Was Flat" tactical Impressionism sets the ship of state adrift. This story suggests, furthermore, that tactical Impressionism may hasten modernity's unraveling effects. 


\section{Impressionism and Kipling's Modernity}

NIETZSCHE THEORIZED THAT A "kind of adaptation to [Modernity's] flood of impressions takes place": As the "tempo of this influx" becomes more "prestissimo," "one instinctively resists taking in anything, taking anything deeply," spending all one's energy, instead, "merely react[ing] to stimuli from outside." People so deluged by impressions "spend their strength partly in assimilating things, partly in defense, partly in opposition," resulting in a "[p]rofound weakening of spontaneity." According to Nietzsche, all the "talents" of "Modernity" are "reactive talents": viz., "the historian, critic, analyst, the interpreter, the observer, the collector, the reader," and, one might add, the Impressionist (47). The talents of Modernity Stalky \& Co. possess are, by contrast, proactive: they are "spontaneous," not reacting to impressions but playing upon reactionary tendencies in their interlocutors.

Where the discourse of the game (with its duty to one's side) meets the discourse of the artist (the highest value of which is sincerity) is in the notion of responsibility. I see Kipling's sense of responsibility widening as his conception of modernity developed. In "The Village That Voted the Earth Was Flat," Kipling warns against the art of lying where it might add to the anarchy of an already impressionistic modernity. As in "The Impressionists," "The Village" puts the reader on the side of revenge-seekers, and, as in "The Impressionists," there is a vicarious sense of power running through the story. Kipling is letting us in on what he calls in the poem appended to the story, "the widest game / That all of a man can play" (Verse 600). The "game" in this instance is a Stalky-style manipulation of prejudices amplified by means of the cheap dailies, the Music Hall, and new media like the cinematograph and phonograph. The story begins when three London newspapermen and an MP are caught speeding through the small town of Huckley. The men are made to appear in court, where the magistrate, also an MP, rebukes and humiliates them, showing off to the assembled villagers. Outside of the courthouse, the men meet Impresario Bat Masquerier, who has been similarly ridiculed and embarrassed. Together, the men vow to take their revenge on the magistrate. The Wildean art of lying is taken to extremes in "The Village." Vivian says in "The Decay of Lying" that, "Art takes life as part of her rough material, recreates it, and refashions it in fresh forms, is absolutely indifferent to fact" (929). In "The Village," Masquerier employs the real Huckley "as a back-cloth to one of his own dramas" (396). Masquerier hires London actors and actresses to stage a revival-type meeting of the "Geoplanarian Society - a society devoted to the proposition that the earth is flat" (388). The event is so successful that the villagers of Huckley, who have been plied with drink, take a vote and hold that the Earth is flat. The rumor of this vote is made by the newspapermen to spread through London. In the meantime, the newspapermen have been disseminating other stories about the backwardness of Huckley. These hijinks culminate in the invention of a satirical song and dance making fun of Huckley. The song, the refrain of which is "the Village that voted the Earth was flat!," takes the London stage by storm, is recorded and distributed around the world: "The Song ran and raped [the world] with the cataleptic kick of 'Ta-ra-ra-boom-de-ay,' multiplied by the West African significance of 'Everybody's doing it,' plus twice the infernal elementality of a certain tune in Dona et Gamma" (394). Unlike "The Impressionists," there is no finally authorized "artist" in "The Village" who can recuperate the truth or restore order: the revengers "did not need to lift [their] little fingers any more than the Alpine climber whose last sentence has unkeyed the arch of the avalanche. The thing roared and pulverised and swept beyond eyesight all by 
itself - all by itself. And once well away, the fall of kingdoms could not have diverted it" (394). As the popularity of "The Song" grows, the original reference to Huckley is forgotten.

After the creators have lost control of their game, the narrating "I" recognizes that "for all practical purposes, literary, dramatic, artistic, social, municipal, political, commercial, and administrative, the Earth was flat" (394). Whereas Stalky \& Co. laugh in relief at the end of "The Impressionists," the erstwhile revengers are ashen-faced at the end of "The Village." The story ends with the men looking on at Parliament, which, in the midst of a vicious sectarian battle, breaks out spontaneously into a rendition of "The Song." It is a fever-dream ending to a fever-pitched story: "The ship of State drifted out helpless on the rocking tide of melody.... They sang 'The Village that voted the Earth was flat': first, because they wanted to, and secondly - which is the terror of that song - because they could not stop" (405). The revengers' game has come to include Parliament, London, the English countryside, the British Empire, the English-speaking world: who knows where it ends, or how? In "The Impressionists" a House, then an entire school is "thoroughly upset" by tactical Impressionism (108). Here the effects are distributed wide and far via a global system of interconnected communities. What was false has become real, and the social consequences of the tactical Impressionism are permanent and impossible to measure. Tactical Impressionism has contributed to the anarchy of modernity.

For the most part, misdirection, although a key component in Kipling's thinking about Impressionism, did not enter into his literary practice. We are not misled in the enigmatic stories like "Wireless" or "The Wish House." Even if we cannot believe that Mr. Shaynor has channeled the ur-Keats or that Mrs. Ashcroft has taken on the pain of Harry, we do not fail to understand these characters or to credit their stories. Rather, we are put into a position from which we may value their experiences regardless of whether we choose to believe as they do in mysterious forces. In a few instances, however, such as "Mrs. Bathurst," Kipling could reproduce his characters' impressions in his readers without offering the paradigm that recuperates their value. Just as Conrad's recourse to such Impressionist techniques as achronology, limited point of view, delayed decoding, and multiple narrators often stems from an appreciation of the violence of experience - its capacity to jar, even to injure the psyche as well as the body - the violence of the men's experience in "Mrs. Bathurst" accounts for the story's irremediably disjointed quality.

"Mrs. Bathurst" is a wandering story, cobbled together piece-meal in the start-and-stop conversation of four working men temporarily made useless in an out-of-the-way corner of the British Empire called "False Bay." It is a story, indeed, of false starts. Before we hear anything of Mrs. Bathurst, we learn of Sergeant Pritchard's misguided attempts to find a farm "back o Vancouver Island": "A day an' a night - eight of us - followin' Boy Niven round an uninhabited island in the Vancouver archipelago!" (330). The narrator has mistimed his trip to Simon's Bay and is stranded there until 5 p.m. Stories are traded of naval incompetence and desertion. Mr. Hooper's impatience when, just as the story seems to be getting to its point, which would appear to be the nature of the relationship between Mrs. Bathurst and Vickery, Pyecroft switches to his account of the early cinema, is offered as a surrogate for the reader's frustration with trying to keep this story in frame. As the extensive critical explication of this tale attests, the story's characters are shadows of persons, illusively seen and depicted. ${ }^{13} \mathrm{Mr}$. Hooper says, "I don't see her yet somehow" in response to Pyecroft's and Pritchard's efforts to convey Mrs. Bathurst, such as offering her personal history, physical appearance, and an anecdote of her behavior. Pyecroft finally conveys Mrs. Bathurst to Mr. Hooper through an unadorned fact which is not about her at all but rather her capacity to leave an impression: 
namely, that Pritchard remembers every moment of his encounters with her, although these amounted to no more than three in ten years (334). Despite or because of their fleeting nature, encounters such as those with which the story is concerned leave their impressions.

Pyecroft describes his piecing-together of Vickery's tale as a working of his "epicycloidal gears" (339). Pyecroft's mechanical images are of a piece with his technical jargon, but the point is also that the working of these gears is never entirely satisfactory. An epicycloid is formed by tracing a line from the fixed point on a wheel as it rolls around the circumference of a fixed circle. When this process is repeated starting from different points on the circle, a wonderfully regular mosaic is formed around the circle. The circumference itself, however, remains undrawn, only returned to again and again. The presence of modernity in "Mrs. Bathurst" is likewise projected in an absent circle at the center of this tale. Britain's empire does not appear in this imagining as a monolithic ordering but as an occasioning of fleeting sensations. The dislocations of modernity - which are figured both in the men's peripatetic lives and in the effect of the early cinema to aggravate Vickery's solipsism, guilt, and infatuation - are not fixed to an interpretive framework but made to disturb the coherence of the story.

"Mrs. Bathurst" is especially mindful of the "hurt" - a word encoded into its title which may be done to the emotional integrity by an inability to sort experiences. The hurts of the story are only secondarily injuries to the flesh, although these are manifold. Vickery loses a quarter of his face to an ammunition hoist, but to be flicked on the raw by an early cinematographic simulacra of Mrs. Bathurst - the most ephemeral, fleeting, and disconnected of experiences - was apparently more than he could bear. The reason the mere impression may hurt appears to be its lack of frame. Pyecroft explains about the cinematograph that "when anyone came down too far towards us that was watchin', they walked right out o' the picture, so to speak," and, sure enough, Mrs. Bathurst "walked on and on till she melted out of the picture - like - like a shadow jumpin' over a candle" (336). It is a maddening form of disappearance, and it is precisely how Vickery disappears at the end of the story, when he walks out of the frame of Pyecroft's account.

The story's conclusion suggests that frameless impressions can wound the sense of coherence, which is presented as an emotional vulnerability. These impressions must be warded off through a communal ritual of shaking-the-head. Because Pyecroft cannot draw the line which connects the dots of what he knows of Vickery's experience - cannot circumscribe Vickery and by this means of categorization protect himself from what he has seen - it is important that he should be allowed to exorcise his impressions: "Well, I don't know how you feel about it," he concludes his account, "but 'avin' seen 'is face for five consecutive nights on end, I'm inclined to finish what's left of the beer an' thank Gawd he's dead!" The "enormous Sergeant of Marines," Pritchard, is left at the story's end with his face in his hands "like a child shutting out an ugliness." His last lines, bearing all the markings of mimetic Impressionism, show what affective dangers lurk in the mere impression: "And to think of her at Hauraki!' he murmured - 'with 'er 'air-ribbon on my beer. "Ada," she said to her niece... Oh, my Gawd!" (341). As critics have recognized, Pritchard's horror is that Mrs. Bathurst should be connected to Vickery's strange fate, not that he presumes her to be the other figure found burned to ashes by Vickery's side. If so, then the source of Pritchard's pain is in the impression of connectedness that yet defies meaningfulness. How could one so lovely be associated to such a gruesome tale? In getting at this question, "Mrs. Bathurst" foregrounds modernity as an immense and bewildering connecting - through new media, through empire, through trains and ships and markets, through word-of-mouth and chance encounters. 
If in our understanding of Impressionism we include Kipling's literary practice and perceptions, then we may see as he did that Impressionism attends the dangers and hurts of a world put into contact by new modes of communication and travel yet wrenched out of context by population growth and by world systems grown wider, more intrusive, and increasingly embattled. The artist behind Kipling's stories was an Impressionist like Conrad who would not exacerbate the impressionistic nature of modernity but seek to ameliorate bewilderment. Perhaps Conrad appreciated this when he praised Kipling's "beautiful squint" for being also "a useful squint," adding: "And - after all - perhaps he sees round the corner? And suppose Truth is just round the corner, like the elusive and useless loafer it is? I can't tell. No one can tell. It is impossible to know. It is impossible to know anything tho' it is possible to believe a thing or two" (CL 1: 369). In the end, Kipling could have said what, as it happens, Conrad said: that "all ambitions are lawful except those which climb upward on the miseries or credulities of mankind" (Personal Record 12). Kipling saw that Impressionism could be used tactically, to survive and to get comeuppance. But Kipling was also an Impressionist with a capital-I, and for literary-Impressionists at the turn of the century, art was a public duty to aid faith, to conduce feeling, and to offer healing. Kipling's stories about tactical Impressionism thus emphasize an ethical injunction, to shore up and not to sever the precarious ties of trust.

\section{University of Texas at Austin}

\section{NOTES}

I wish to thank Allen MacDuffie for reading many drafts of this essay and offering excellent guidance at every stage of development. I am also grateful to Neville Hoad, Jake Ptacek, and Parama Roy, whose constructive criticism improved this essay.

1. For the best discussions of Conrad's own views on Impressionism, see Hay, Knowles and Moore 166-68, and Karl 409-10. Peters and Johnson have situated Conrad's aesthetics more broadly within Impressionist epistemologies.

2. Kucich argues that Kipling's "broadened middle-class appeal" derived from two strategies, which are on display in Stalky \& Co.: the utilization of sadomasochism to produce a dynamic of insiders and outsiders and a blending of "upper- and lower-middle-class ideological languages" of evangelism and professionalism (57-59). Deane reads the Stalky stories in support for his argument that "Kipling recommends an imperialism that does not conform to conventional civilized virtues or to traditional liberal justifications, but in place of these he proposes an apparently coherent honor code through which competitive manliness can make the entire enterprise virtuous, meaningful, and satisfying" (48).

3. For this reason, the story is Salman Rushdie's favorite of Kipling's tales. See Rushdie 74-80.

4. Saunders synthesizes the vast scholarship on Impressionism in his excellent entry in the Companion to Modernist Literature and Culture (2008).

5. See, especially, Armstrong, Bender, van Gunsteren, Hoople, Nagel, Fried, Peters, and Stowell.

6. Miller has argued that the "typically high modernist concern [is] with the confusion of the individual trying to make sense of a bewildering cosmos" (147), while, as Parkes and Wollaeger have shown, the bewilderment explored by literary Impressionists was decidedly less "cosmic" than quotidian. Ford Maddox Ford and Conrad, for example, connect Impressionism to propaganda and sensationalist journalism. See, respectively, Wollaeger 128-63 and Parkes 99-146. 
7. Drawing on Lycett's and Flanders's biographies, Berrong offers a concise rehearsal of Kipling's family connections to artists and Parisian Impressionism:

[Kipling] was the son of an art teacher and talented draftsman, Lockwood Kipling, who, when they visited the Paris Universal Exposition in April 1878, prompted the then thirteen-year-old boy to visit art galleries and that year's Salon (Lycett 56). He spent his English Christmases with his Aunt Georgie and her husband, the distinguished Pre-Raphaelite painter Edward BurneJones. Another of his aunts, Agnes, had married the Orientalist academic painter Edward Poynter, who had known James Whistler in Paris and studied there with Charles Gleyre at the same time as Claude Monet (Flanders 104). After Whistler sued Ruskin for libeling his work neither Burne-Jones nor Poynter seems to have thought much of him or it (Flanders 256), but they continued to be aware of what was going on in modern French painting. In 1888 Whistler, by then a friend of Monet, married Beatrice Godwin, the widowed daughter of Lockwood Kipling's artistic mentor, John Birnie Philip (Lycett 64). Rudyard's familiarity with Whistler's style by the time he began work on his first novel is demonstrated by the fact that he entitled one of four sketches he did for his friend Edmonia Hill in early 1889 'Study (after the fashion of Whistler)' (Lycett 171). (Berrong 25)

8. For an overview and explication of "the impression" in eighteenth- and nineteenth-century thought and literature, see Matz 12-52. Shiff (27-38) offers a similar account of the synthesizing function of the "impression" for French Impressionist painters and art critics.

9. The Sino-Japanese War (1894-1895) was a potent reminder of Japan's militarism. The Russo-Japanese War (1904-1905) would put an end to Japonisme by "chang[ing] the image of Japan from the nation of flowery beauty to that of might" (Chiba 3 ).

10. As Matz has explained, the "impression" in Impressionist theory is no mere inkling but a transcendent experience binding sensation to a universal reality, serving thus as the grounds for community. Matz writes: "Beyond Hume but prior to Husserl, with greater breadth than empirical psychology, the impression's perceptual aspirations and uncertainties match those at work when idealism tries to subsume Empiricism by distinguishing a faculty, synthetic in function and dialectical in process, through which the transcendent and the real interact" (29). Neither wholly in the individual psychology nor in the shared sphere of meaning nor yet in the objective world but somehow part and parcel of all these, the impression was an attempt to ground reality in the synthesis of intuition and observation. Such a valorized notion of the "impression" goes some way to explaining why for Conrad "an impression conveyed through the senses" should be capable of revealing "the solidarity in mysterious origin, in toil, in joy, in hope, in uncertain fate which binds men to each other and all mankind to the visible world" ("Preface" 1). That Kipling felt a need to shore up mimetic Impressionism with persuasive techniques reveals his doubts about the impression as a means of access to universal reality.

11. This claim, which originates in Jameson, has been investigated in detail by Parkes.

12. See, especially, Armstrong 261-70.

13. The Kipling Society has very helpfully reviewed half a century's criticism on "Mrs. Bathurst" in the online Readers' Guide to the Works of Rudyard Kipling.

\section{WORKS CITED}

Armstrong, Paul B. The Challenge of Bewilderment: Understanding and Representation in James, Conrad, and Ford. Ithaca: Cornell UP, 1987.

Bender, Todd K. Literary Impressionism in Jean Rhys, Ford Madox Ford, Joseph Conrad, and Charlotte Brontë. New York and London: Garland, 1997. 
Berrong, Richard M. “'Three Dabs and Two Scratches': Painterly Impressionism in The Light That Failed.” Kipling Journal 87.349 (2013): 25-38.

Canby, Henry Seidel. The Short Story. New York: Henry Holt, 1902.

Carrington, Charles. Rudyard Kipling: His Life and Work. $3^{\text {rd }}$ ed. London: Macmillan, 1978.

Chiba, Yoko. “Japonisme': East-West Renaissance in the Late 19th Century.” Mosaic: A Journal for the Interdisciplinary Study of Literature 31.2 (1998): 1-20.

Conrad, Joseph. The Collected Letters of Joseph Conrad. Volume 1: 1861-1897. Ed. Frederick R. Karl and Laurence Davies. Cambridge: Cambridge UP, 1983.

. A Personal Record. New York: Harper \& Brothers, 1912.

. "Preface." The Nigger of the "Narcissus". New York: Penguin, 1989. xlvii-li.

Deane, Bradley. Masculinity and the New Imperialism: Rewriting Manhood in British Popular Literature, 1870-1914. Cambridge: Cambridge UP, 2014.

Flanders, Judith. A Circle of Sisters: Alice Kipling, Georgina Burne-Jones, Agnes Poynter and Louisa Baldwin. New York: Norton, 2005.

Fried, Michael. “Almayer's Face: On 'Impressionism' in Conrad, Crane, and Norris.” Critical Inquiry 17.1 (1990): 193-236.

- Manet's Modernism, Or, the Face of Painting in the 1860s. Chicago: U of Chicago P, 1996.

Green, Roger Lancelyn, ed. Kipling: The Critical Heritage. New York: Barnes \& Noble, 1971.

Hay, Eloise Knapp. "Joseph Conrad and Impressionism." Journal of Aesthetics and Art Criticism 34.2 (1975): 137-44.

Hoople, Robin P. In Darkest James: Reviewing Impressionism, 1900-1905. Lewisburg: Bucknell UP, 2000.

"Impression." OED Online. Oxford UP. March 2013. Web. 23 May 2013.

Jameson, Fredric. The Political Unconscious: Narrative as a Socially Symbolic Act. Ithaca: Cornell UP, 1981.

Jarrell, Randall. Kipling, Auden \& Co: Essays and Reviews, 1935-1964. New York: Farrar, Straus and Giroux, 1980.

Johnson, Bruce. "Conrad's Impressionism and Watt's 'Delayed Decoding."” Conrad Revisited: Essays for the Eighties. Ed. Ross C. Murfin. Tuscaloosa: U of Alabama P, 1985.

Karl, Frederick R. Joseph Conrad: The Three Lives, A Biography. New York: Farrar, Straus and Giroux, 1979.

Kawakita, Michiaki. “The World of Shibui." Japan Quarterly 8.1 (1961): 33-42.

Kipling, Rudyard. The Complete Stalky \& Co. New York: Oxford UP, 2009.

- From Sea to Sea. Vol.1. New York: Doubleday, 1913.

. "Mrs. Bathurst." The Man Who Would Be King. New York: Penguin, 2011. 327-41.

. Rudyard Kipling's Verse: Inclusive Edition: 1885-1918. New York: Doubleday, Page, 1922.

. Something of Myself: For My Friends Known and Unknown. New York: Penguin, 1992.

- "The Village That Voted the Earth Was Flat." The Man Who Would Be King. New York: Penguin, 2011. 377-406.

Knowles, Owen, and Gene M. Moore. Oxford Reader's Companion to Conrad. Oxford: Oxford UP, 2000.

Kucich, John. "Sadomasochism and the Magical Group: Kipling's Middle-Class Imperialism." Victorian Studies 46.1 (2003): 33-68.

Lambourne, Lionel. Japonisme: Cultural Crossings between Japan and the West. New York: Phaidon, 2005.

Lycett, Andrew. Rudyard Kipling. London: Wiedenfeld and Nicolson, 1999.

Matz, Jesse. Literary Impressionism and Modernist Aesthetics. Cambridge: Cambridge UP, 2001.

Menand, Louis. "Kipling in the History of Forms." High and Low Moderns: Literature and Culture, 18891939. Ed. Maria DiBattista and Lucy McDiarmid. New York: Oxford UP, 1996. 148-65.

Miller, Tyrus. Late Modernism: Politics, Fiction, and the Arts between the World Wars. Berkeley: U California P, 1999.

“Mrs. Bathurst: The Critics, 1955-1999." The Kipling Society Readers' Guide. The Kipling Society, 1 March 2010. Web. 23 May 2013. 
Nagel, Thomas. "What is it like to be a bat?" Philosophical Review 83.4 (1974): 435-50.

Nietzsche, Friedrich. The Will to Power. Ed. Kaufman. Trans. Walter Kaufmann and R. J. Hollingdale. New York: Vintage, 1968.

Page, David. “Notes on From Sea to Sea. No. XI.” The Kipling Society Readers' Guide. The Kipling Society, 1 March 2010. Web. 23 May 2013.

Parkes, Adam. A Sense of Shock: The Impact of Impressionism on Modern British and Irish Writing. New York: Oxford UP, 2011.

Peters, John G. Conrad and Impressionism. Cambridge: Cambridge UP, 2001.

Ricketts, Harry. "A Short Walk on the Wilde Side: Kipling's First Impressions of Japan.” New Zealand Journal of Asian Studies 5.2 (Dec. 2003): 26-32.

Rushie, Salman. Imaginary Homelands. London: Granta, 1991.

Said, Edward. Introduction. Kim. By Rudyard Kipling. New York: Penguin, 2011. 291-331.

Saunders, Max. "Literary Impressionism." A Companion to Modernist Literature and Culture. Ed. David Bradshaw and Kevin J. H. Dettmar. Oxford: Wiley-Blackwell, 2008. 204-11.

Sherry, Norman, ed. Conrad: The Critical Heritage. London: Routledge and Kegan Paul, 1973.

"Shibui." OED Online. Oxford UP. March 2013. Web. 23 May 2013

"Shibuichi." OED Online. Oxford UP. March 2013. Web. 23 May 2013.

Shiff, Richard. Cezanne and the End of Impressionism: A Study of the Theory, Technique, and Critical Evaluation of Modern Art. Chicago: Chicago UP, 1984.

Sichel, Walter Sydney. "Fathers of Literary Impressionism in England." Quarterly Review 185 (1897): 173-94.

Stewart, Garrett. Review. Literary Impressionism and Modernist Aesthetics. By Jesse Matz. Modernism/modernity 10.4 (2003): 770-72.

Stowell, Peter H. Literary Impressionism, James and Chekhov. Athens: U of Georgia P, 1980.

Tompkins, J. M. S. The Art of Rudyard Kipling. London: Methuen, 1965.

van Gunsteren, Julia. Katherine Mansfield and Literary Impressionism. Amsterdam: Rodopi, 1990.

White, Gleeson. Letters to Eminent Hands. Derby: Frank Murray, 1892.

Wichmann, Siegfried. Japonisme: The Japanese Influence on Western Art since 1858. New York: Thames \& Hudson, 1999.

Wilde, Oscar. "The Decay of Lying." The Collected Works of Oscar Wilde. London: Wordsworth, 1997. 919-44.

Wollaeger, Mark. Modernism, Media, and Propaganda: British Narrative from 1900 to 1945. Princeton: Princeton UP, 2006.

Yeats, W. B. Letters to the New Island. Ed. Horace Reynolds. 1934. London: Oxford UP, 1970. 